\title{
The Reliability and Validity of the Korean Edition of the CSBS DP Caregiver Questionnaire
}

\author{
Yoonkyoung Lee ${ }^{\mathrm{a}}$, Jieun Choi ${ }^{\mathrm{a}}$, HyoJoo Lee ${ }^{\mathrm{a}, \mathrm{b}}$ \\ ${ }^{a}$ Division of Speech Pathology and Audiology, Hallym University, Chuncheon, Korea \\ ${ }^{b}$ Hallym Speech-Language Pathology, Gimpo, Korea
}

Correspondence: YoonKyoung Lee, $\mathrm{PhD}$ Division of Speech Pathology and Audiology, College of Natural Sciences, Hallym University, 1 Hallymdaehak-gil, Chuncheon 24252, Korea Tel: +82-33-248-2219

Fax: +82-33-256-3420

E-mail: ylee@hallym.ac.kr

Received: January 20, 2021

Revised: February 8, 2021

Accepted: February 8, 2021

This research was supported by Hallym University Research Fund 2019 (HRF 201909-014).

\begin{abstract}
Objectives: The Communication and Symbolic Behavior Scale Developmental Profile (CSBS DP) consists of three subtests: Infant Toddler Checklist (ITC), Behavior Sample (BS), and Caregiver Questionnaire (CQ). While the reliability and validity of the Korean edition of the CSBS DP BS had been previously reported, the reliability and validity of other two tests have not reported yet. This study aimed to examine that the reliability and validity of the Korean edition of the CSBS DP CQ. Methods: The CSBS DP CQ was translated into Korean and then reviewed by 3 child language professionals for the accuracy of the translation. 794 caregivers who have typically developing toddlers age ranged from 6-24 months completed the KCSBS DP CQ and 679 data had been analyzed among them. The reliability by internal consistency, the concurrent validity by correlation between K-CSBS DP BS and SELSI each, the construct validity by confirmation factor analysis, and the developmental validity by ANOVA according to age group measured. Results: The reliability of the K-CSBS DP CQ measured by internal consistency was high and the correlation measured with the K-CSBS DP BS and SELSI were each significant as well. The results of confirmatory factor analysis confirmed the three factors (social, speech, and symbolic) of the original CSBS DP CQ and the developmental validity was confirmed by results of ANOVA. Conclusion: Through this study, the K-CSBS DP CQ has been confirmed as a valid and reliable for assessing early communication of Korean toddlers. It can be used for assessing early communication abilities of typically developing toddlers and children with developmental disabilities as well.
\end{abstract}

Keywords: CSBS DP Caregiver Questionnaire, Validity, Reliability
발달지연 아동을 이른 시기에 확인하는 것은 조기중재로 연결되 므로 매우 중요하다. 어린 시기에 중재가 제공될수록 발달의 예후 가 좋을 뿐 아니라, 가족들이 아동의 문제를 이해하고 효율적으로 대처할 수 있으므로 아동과 가족 모두에게 긍정적인 효과를 갖게 되기 때문이다. 특히 언어와 의사소통 발달은 그 자체로도 매우 중 요하지만, 인지나 사회성 발달과 같이 다른 영역의 발달에는 물론 사회적 적응에도 큰 영향을 미치므로 더욱 중요하다 할 수 있다 (Lee, 2011, 2019).

가능한 이른 시기에 조기중재가 필요한 아동을 확인하는 것의 중요함이 강조되고 있음에도 불구하고, 조기중재가 필요한 아동을 결정하는 것이 쉽지 않다. 나이가 어린 영유아기는 발달 시기나 속 도에 개인차가 다른 시기에 비해 크므로 어느 정도 지연된 경우를
조기중재가 필요한 아동으로 볼 것인가에 대해서 이견이 존재할 뿐 아니라 특정 시기의 평가 결과만으로 발달지연 여부를 결정하는 것 도 쉬운 일이 아니기 때문이다. 특히 언어 발달의 경우에는 많은 아 동들이 첫돌을 전후해서 첫 낱말을 산출하지만, 상당수는 18 개월 정도까지, 일부는 20 개월 전후해서 뒤늦게 첫 낱말을 산출하기도 하여 전형적 발달에 대한 폭이 크며(Rescorla, 2013), 또래에 비해 초기 언어 발달이 느린 아동들 중 상당수는 특별한 중재 없이도 뒤 늦게 또래들을 따라잡기도 하므로(Dale, Price, Bishop, \& Plomin, 2003; Henrichs et al., 2011; Paul, Looney, \& Dahm, 1991; Rescorla, Roberts, \& Dahlsgaard, 1997; Tomblin, Records, Buckwalter, Zhang, Smith, \& O’Brien, 1997; Westerlund, Berglund, \& Eriksson, 2006), 조기중재 여부 결정을 어렵게 한다. 때문에 언어표현이 느린 아동 
들도 바로 평가나 중재에 의뢰되지 않고 24 개월 이후로 의뢰가 미 뤼지는 경우가 흔하며, 의학적으로나 발달적으로 다른 위험 요인이 없는 경우에는 30 개월 이후까지도 의뢰가 늦어지기도 한다. 이런 이유들로 조기중재가 필요한 아동을 확인하는 것은 임상가들에게 중요한 과업이라 할수 있다.

언어표현 이전부터 발달을 시작하는 언어이전기 의사소통행동 또는 초기 사회적 의사소통행동은 이른 시기에 조기중재가 필요한 아동을 결정하는데 도움이 될 수 있다(Lee \& Lee, 2019). 아동들은 언어를 표현하기 전부터 자기의 행동이 상대방에게 영향을 미칠 수 있다는 사실을 인식하고, 몸짓이나 소리내기와 같은 비언어적 수단 을 사용하여 의사소통을 시작한다. 이러한 비언어적 의사소통행 동은 이후 언어적 의사소통 발달의 토대가 되며, 이후 발달을 예측 할 수 있게 한다(Lee, 2019; Lee \& Lee, 2016, 2019). 실제로 많은 연 구들은 언어이전 시기의 몸짓과 발성, 의사소통기능, 언어이해, 상 징놀이 등과 같은 행동 발달이 이후 2,3 세 경의 언어 발달을 예측 할 수 있었다고 보고하였다(Calandrella \& Wilcox, 2000; Choi \& Lee, 2018; Hong \& Kim, 2005; Iverson \& Goldin-Meadow, 2005; Thal \& Tobias, 1992; Thal, Tobias, \& Morrison, 1991; Watt, Wetherby, \& Shumway, 2006). 이러한 연구 결과들은 언어이전기의 의사 소통행동 발달이 언어발달이 지연된 아동들을 더 이른 시기에 확 인할 수 있게 할 뿐만 아니라 나아가 언어 문제가 이후까지도 지속 될 가능성이 있는 아동들과 자발적으로 또래 수준을 회복할 수 있 는 아동들을 구별하는 데에도 큰 의미를 갖는다.

언어이전기의 의사소통행동 발달이 발달지연 아동의 조기 발견 에 갖는 시사점에도 불구하고 영유아를 대상으로 개발되어 있는 대부분의 공식언어검사들은 어휘나 문법 등 언어적 상징 체계에 대 한 이해나 표현을 중심으로 평가하며, 언어이전기의 의사소통행동 을 평가하는 도구는 많지 않다. 그 중 Communication and Symbolic Behavior Scale: Developmental Profile (이하 CSBS DP; Wetherby \& Prizant, 2002)은 언어이전기부터 초기 언어습득기까지, 초기 의사소통행동을 평가하는 대표적 검사로 알려져 있다. CSBS DP는 선행연구를 통해 이후 언어 발달과 관련이 깊은 것으로 보고된 정 서 및 시선, 의도적 의사소통행동, 의사소통적 몸짓, 말소리, 언어이 해, 사물사용 및 놀이 등을 주요 평가 내용으로 평가하고 있다.

CSBS DP는 선별검사인 Infant Toddler Checklist (ITC)와 CSBS $\mathrm{DP}$ 행동표본검사, 그리고 CSBS DP 양육자설문검사 세 가지 검사 로 구성되어 있다. ITC를 통해 의사소통 발달 위험으로 선별되면, 그 다음 절차로 CSBS DP 행동표본검사와 CSBS DP 양육자설문검 사를 사용해서 심화평가를 진행하도록 권고된다. CSBS DP 행동표 본검사는 반구조화된 절차를 통해 얻어진 행동 표본을 체계화된
채점 체계를 기반으로 평가하도록 고안되어 있으며, CSBS DP 양육 자설문검사는 같은 평가 내용을 아동의 행동을 잘 알고 있는 주양 육자에게 설문지를 통해 평가하도록 되어 있다. 일반적으로 나이가 어린 영유아들은 검사 지시를 잘 따르지 못해서 구조화된 검사에 잘 반응하지 못하거나, 채점 기준에 제시된 양식으로 정확하게 반 응하지 않아서 직접검사를 통한 평가가 어렵다. 때문에 많은 연구 자나 임상가들은 어린 영유아들을 평가할 때 구조화된 직접검사 보다는 행동 관찰을 기반으로 한 평가 방식을 활용할 것을 권고한 다(Crais, 2011; Lee, 2019). 더불어 일상의 자연스러운 상황에서 아 동과 많은 시간을 보내는 가족들을 평가에 반드시 포함하고 이들 의 의견을 반영함으로써 검사자가 얻은 정보의 타당도와 신뢰도를 높이도록 강조한다(Lee, 2019; Lynch \& Hanson, 2004; Rossetti, 2001). CSBS DP는 관찰을 기반으로 한 행동표본검사와 양육자설 문검사 두 가지 방식을 통해 동일한 행동을 평가하고 종합하여 아 동의 의사소통 발달에 대한 신뢰롭고 타당한 결과를 얻을 수 있도 록 고려하였다.

CSBS DP 행동표본검사는 Lee, Lee와 Choi (2018)에 의해 한국 어로 번역하고 수정된 후 $12-24$ 개월 사이의 전형적 발달을 보이는 우리나라 영아 290명을 대상으로 신뢰도와 타당도가 이미 보고되 었다. 반면, CSBS DP 양육자설문검사는 아직 우리나라 아동들을 대상으로 타당도와 신뢰도가 검정되지 않았다. 검사가 개발된 미국 에서는 6-24개월 사이의 전형적 발달 영아 790명을 대상으로 Chronbach $\alpha$ 와 재검사신뢰도를 통해 신뢰도가 보고되었으며, 검사 세부 요인과 구성영역들 간의 상관 분석을 통해 구인타당도가, 그리고 $\mathrm{CSBS}$ DP 행동표본검사와의 상관분석을 통해 공인타당도가 보고 되어 있다.

CSBS DP 양육자설문검사가 우리나라 아동들을 대상으로 활용 될 수 있는지를 결정하기 위해서는 검사의 타당도와 신뢰도 검정이 선행되어야 할 것이다. 본 연구는 이러한 배경 하에 우리나라 영아 를 대상으로 CSBS DP 양육자설문검사의 타당도와 신뢰도 확인을 목적으로 하였다. 타당도와 신뢰도는 여러 방법을 통해서 검정할 수 있으나, 본 연구에서는 원검사 결과와의 비교를 위해 Chronbach $\alpha$ 문항내적일관도를 통해 신뢰도를, CSBS DP 행동표본검사와의 상 관분석을 통해 공인타당도를 검정하였다. 그리고 이에 더하여 국내 영아를 대상으로 타당도가 보고된 영유아 언어발달검사(Sequenced Language Scale for Infants; Kim, Kim, Yoon, \& Kim, 2003)와의 공 인타당도를, 이미 검사 요인이 결정되어 있는 검사이므로 확인적 요 인검사를 통한 구인타당도를, 그리고 마지막으로 연령 집단 간의 차이검정을 통해 발달적 타당도를 추가하여 검정하였다. 본 연구의 결과는 초기 의사소통 발달 수준에 있는 우리나라 아동들에게 
CSBS DP 양육자설문검사의 활용을 위한 기반을 제공할 수 있을 것이다.

\section{연구방법}

\section{연구참가자}

본 연구에는 6 개월에서 24 개월에 해당하는 영아 794 명이 참여하 였다. 연구참가자는 영아선별·교육진단검사(Developmental assessment for the Early intervention Program planning, DEP; Jang, Seo,

Table 1. Demographic information of toddlers

\begin{tabular}{lcccr}
\hline Age group & Mean age $(\mathrm{mo})$ & Boy & Girl & Total \\
\hline $6-7$ & 6.36 & $17(47.2)$ & $19(52.8)$ & $36(100)$ \\
$8-9$ & 8.64 & $27(52.9)$ & $24(47.1)$ & $51(100)$ \\
$10-11$ & 10.66 & $10(47.6)$ & $11(52.4)$ & $21(100)$ \\
12 & 12.00 & $23(52.3)$ & $21(47.7)$ & $44(100)$ \\
$13-14$ & 13.47 & $24(52.2)$ & $22(47.8)$ & $46(100)$ \\
$15-16$ & 15.53 & $37(50.7)$ & $36(49.3)$ & $73(100)$ \\
$17-18$ & 17.57 & $55(52.9)$ & $49(47.1)$ & $104(100)$ \\
$19-20$ & 19.54 & $36(47.4)$ & $40(52.6)$ & $76(100)$ \\
$21-22$ & 21.55 & $57(47.5)$ & $63(52.5)$ & $120(100)$ \\
$23-24$ & 23.53 & $55(52.4)$ & $50(47.6)$ & $105(100)$ \\
Total & 16.91 & $341(50.4)$ & $335(49.6)$ & $676(100)$ \\
\hline
\end{tabular}

Values are presented as number (\%).

$\mathrm{Mo}=$ month.
\& Ha, 2011) 또는 영유아 언어발달검사(SELSI; Kim, et al., 2003)에 서 정상 범위에 속하는 영아로 한정하였다. SELSI는 수용언어와 표 현언어 결과가 백분위수 15 이상을, $\mathrm{DEP}$ 결과는 총점이 정상 발달 (25 백분위수)에 해당하는 경우를 정상 범위로 설정하였으며, 이에 미달한 영아 65 명을 제외하였다. 또한 연령 성비를 비슷하게 하기 위하여 여아와 남아의 성별 성비 차이를 $5 \%$ 이내로 조정하였으며 이 과정에서 추가로 53명이 제외되어 총 676명만 포함하였다. 미국 판 원검사는 총 790 명의 영아를 대상으로 표준화 되어 양국의 아동 인구수를 고려할 때 사례 수는 양호한 것으로 고려되었다.

연령 집단은 미국판 CSBS DP (Wetherby \& Prizant, 2002) 양육 자설문검사와 동일하게 6-7개월, 10-11개월, 12 개월, $13-14$ 개월, $15-16$ 개월, $17-18$ 개월, $19-20$ 개월, 21-22개월, 23-24개월의, 10 개 연 령 집단으로 구분하였다. 각 집단 별 참가자수는 21 명에서 120 명이 었다. 6-7개월과 10-11개월의 참가자 수가 상대적으로 적었으나 미 국판 원검사에서도 6-7개월은 12명, 8-9개월 47명, 10-11개월 53명 으로 참가자 수가 상대적으로 적어 그대로 분석하였다. 연구에 참 여한 영아의 성별은 남아 341명(50.4\%), 여아 335명(49.6\%)으로 비 율이 비슷하였다(Table 1).

연구참가자 배경 정보는 Table 2에 제시하였다. 영아의 부모 대부 분은 고졸 이상이었으며, 평균 월수입은 300 만원 이상인 것으로 나 타났다. 가계소득이 100 만원 미만이었던 세 가정은 부모가 아직 대

Table 2. Demographic information of participants' parents

\begin{tabular}{|c|c|c|c|c|c|c|c|c|c|c|c|}
\hline & $6-7$ & $8-9$ & $10-11$ & 12 & $13-14$ & $15-16$ & $17-18$ & $19-20$ & $21-22$ & $23-24$ & Total \\
\hline \multicolumn{12}{|c|}{ Education level of parents } \\
\hline \multicolumn{12}{|l|}{ Father } \\
\hline High school & $5(15.2)$ & $7(16.3)$ & $5(26.3)$ & $4(9.5)$ & $4(11.1)$ & $8(12.1)$ & $9(9.2)$ & $6(9.4)$ & $12(10.9)$ & $11(11.5)$ & $71(11.7)$ \\
\hline Junior college & $0(0.0)$ & $2(4.7)$ & $0(0.0$ & $3(7.1)$ & $1(2.8)$ & $2(3.0)$ & $5(5.1)$ & $3(4.7)$ & $5(4.5)$ & $0(0.0)$ & $21(3.4)$ \\
\hline College & $22(66.7)$ & $29(67.4)$ & $13(68.4)$ & $27(64.3)$ & $25(69.4)$ & 52 (78.8) & $80(81.6)$ & $50(78.1)$ & $79(71.8)$ & $78(79.6)$ & $455(74.7)$ \\
\hline Graduate school & $6(18.2)$ & $5(11.6)$ & $1(5.3)$ & $8(19.0)$ & $6(16.7)$ & $4(6.1)$ & $4(4.1)$ & $5(7.8)$ & $14(12.7)$ & $9(9.2)$ & $62(10.2)$ \\
\hline \multicolumn{12}{|l|}{ Mother } \\
\hline High school & $1(3.0)$ & $8(18.6)$ & $1(5.3)$ & $1(2.4)$ & $4(11.1)$ & $9(12.9)$ & $11(11.2)$ & $9(14.5)$ & $13(11.6)$ & $15(15.0)$ & $72(11.7)$ \\
\hline Junior college & $1(3.0)$ & $2(4.7)$ & $2(10.5)$ & $4(9.5)$ & $6(16.7)$ & $2(2.9)$ & $5(5.1)$ & $4(6.5)$ & $8(7.1)$ & $3(3.0)$ & $37(6.0)$ \\
\hline College & $24(72.7)$ & $29(67.4)$ & $13(68.4)$ & $34(81.0)$ & $18(50.0)$ & $50(71.4)$ & $72(73.5)$ & $43(69.4)$ & $74(66.1)$ & $76(76.0)$ & $433(70.4)$ \\
\hline Graduate school & $7(21.2)$ & $4(9.3)$ & $3(15.8)$ & $3(7.1)$ & $8(22.2)$ & $9(12.9)$ & $10(10.2)$ & $6(9.7)$ & $17(15.2)$ & $6(6.0)$ & $73(11.9)$ \\
\hline \multicolumn{12}{|c|}{ Average monthly income (million KRW) } \\
\hline$<1$ & $0(0.0)$ & $0(0.0)$ & $0(0.0)$ & $0(0.0)$ & $0(0.0)$ & $1(1.5)$ & $0(0.0)$ & $0(0.0)$ & $1(0.9)$ & $1(1.0)$ & $3(0.5)$ \\
\hline $1-2$ & $2(5.9)$ & $5(11.4)$ & $0(0.0)$ & $4(9.8)$ & $0(0.0)$ & $2(2.9)$ & $1(1.0)$ & $0(0.0)$ & $3(2.8)$ & $3(3.0)$ & $20(3.2)$ \\
\hline $2-3$ & $6(17.6)$ & 14 (31.8) & $3(15.0)$ & $7(17.1)$ & $9(22.5)$ & $15(22.1)$ & $24(25.0)$ & $14(20.0)$ & $22(20.2)$ & $20(20.2)$ & 134 (21.6) \\
\hline $3-4$ & 11 (32.4) & $16(36.4)$ & $4(20.0)$ & $10(24.4)$ & $9(22.5)$ & $19(27.9)$ & 32 (33.3) & $23(32.9)$ & $24(22.0)$ & $28(28.3)$ & $176(28.3)$ \\
\hline $4-5$ & $9(26.5)$ & $4(9.1)$ & $7(35.0)$ & 11 (26.8) & $12(30.0)$ & 11 (16.2) & $19(19.8)$ & $16(22.9)$ & $24(22.0)$ & 22 (22.2) & $135(21.7)$ \\
\hline$>5$ & $6(17.6)$ & $5(11.4)$ & $6(30.0)$ & $9(22.0)$ & $10(25.0)$ & $20(29.4)$ & $20(20.8)$ & $17(24.3)$ & $35(32.1)$ & $25(25.3)$ & 153 (24.6) \\
\hline
\end{tabular}

Values are presented as number (\%). 
학원생이어서 고정 수입이 제한된 경우였으므로 제외하지 않고 포 함하였다.

\section{연구도구}

\section{CSBS DP 양육자설문검사}

CSBS DP 양육자설문검사는 CSBS DP를 구성하는 세 검사(ITC, CSBS DP 행동표본검사, CSBS DP 양육자설문검사) 중 하나로, 부 모 또는 양육자 보고를 통해 실시하는 평가 도구이다. 검사자의 설 명 없이도 양육자가 읽고 답할 수 있도록 고안되었으며, CSBS DP 행동표본검사와 동일하게 3 개의 구성영역(사회적, 발화적, 상징적), 7개의 세부요인(정서 및 시선, 의사소통, 몸짓, 말소리, 낱말, 이해, 사물사용)을 평가한다. 총 41 개의 다중선택(네, 아니오, 관찰안됨) 문항으로 이루어져 있으며, 검사는 약 15-20분 정도 소요된다.

CSBS DP 양육자설문검사는 미국판 원검사를 그대로 번역하였 으며 언어적 차이를 반영하기 위해 말소리를 평가하는 23번 문항과 수용어휘와 표현어휘를 평가하는 26번, 32 번 문항만 일부 수정하 였다. 23번 말소리 평가 문항의 경우는 CSBS DP 행동표본검사(Lee et al., 2018)와 동일하게 원검사에 포함된 10 개의 말소리 $/ \mathrm{m} /, \mathrm{n} /$, /b/, /d/, /g/, /w/, /l/, /y/, /s/, /sh/를 /ㅁ/, / ᄂ/, /ㅂ/, /ㄷ/, / ᄀ/, /O/, /ㄹ/, $/$ ㅈ/,/人/,/ㅎ/로 대체하였다. $/ \mathrm{m} /, / \mathrm{n} /, / \mathrm{b} /, / \mathrm{d} /, / \mathrm{g} /, / \mathrm{l} /, / \mathrm{s} /$ 는 우리 말소 리 중 조음위치와 조음방법이 동일하거나 유사한 말소리 /ㅁ/,/ㄴ/, /ㅂ/,/ㄷ/,/ᄀᄀ/,/ㄹ/,/ / 시로 대체하였으며, 영어권 말소리에만 존재하 는 $/ \mathrm{sh} /, / \mathrm{w} /, / \mathrm{y} /$ 는 우리나라 영아의 말소리 발달을 고려하여 /ㅈ/ /, /ㅎ/,/O/로 대체하였다(Kim, Pae, \& Park, 2007)./ㅎㅇㅢ 경우는 영 어권에서는 초성에서 빈번하게 생략되어 말소리 목록에서 제외된 듯하나 우리 말소리에서는 낱말 첫소리에서 조음되는 경우가 많기 때문에 포함하였으며, 원검사에서는 모두 초성 위치의 소리만을 포 함하였으나 초성 위치에서 포함할 수 있는 자음군이 이미 모두 평 가 항목으로 포함되어 우리나라 영유아 말소리발달 자료를 참조하 여 종성 위치에서만 산출되는 / $/$ /을 포함하였다. 각 말소리가 포함 된 낱말의 예시는 영아기 어휘 목록(Lee, Chang, Choi, \& Lee, 2009; Pae \& Kwak, 2011)을 참조하여 포함하였다.

26 번과 32 번 어휘 평가 문항은 미국판 원검사의 어휘 36 개를 번 역한 후 한국어로 대체가 어렵거나 상대적으로 자주 사용되지 않 는 일부 낱말들(예, uh oh, outside, trucks 등)은 우리나라 영아의 어휘발달 자료(Lee et al., 2009)와 한국판 M-B CDI (Pae \& Kwak, 2011)의 어휘 목록을 참조하여 다른 낱말로 대체하였으며, 우리나 라 영아들에게 고빈도로 출현하는 낱말을 13 개 추가하여 총 49 개 의 낱말로 구성하였다.

번역 - 수정 한 CSBS DP 양육자설문검사는 아동언어발달 또는
아동언어장애 분야 박사학위 소지자 3 명에게 각 문항별 번역 적정 성과 수정된 문항의 적정성에 대해 5 점 척도로 내용타당도 평가를 실시하였으며 4.8 로 비교적 높은 타당도 결과를 받았다. 번역이나 한국 자료로 대체한 일부 어휘 항목과 관련하여 일부 제안된 사항에 대해서는 수정하였다. 수정된 검사지는 연령 집단 별 10-20명, 총 298 명 영아 양육자를 대상으로 예비검사를 실시하였다. 예비검사 결과 를 토대로 어휘 문항의 항목은 TestAn 1.0 프로그램(Sung, 2015)을 활 용해 측정된 난이도와 변별도를 기반으로 미국판 원검사와 동일한 문항수인 36 개 어휘로 최종 결정하였다. 최종 결정된 어휘는 원검사 와 18 개가 변경되었으며, 낱말 범주는 가족 명칭, 동물 이름, 신체부 위 이름, 사회적 어휘(인사말 등), 생활용품, 음식, 장난감의 범주로 미국판 원검사와 동일하였다. 미국판 원검사와 비교하였을 때, 한국 판에는 동물 이름, 먹을 것, 동사가 각각 2,3 개 정도 많이 포함되었으 며, 반대로 신체 부위나 사회적 어휘는 각 2,3 개 적었다. 그 외 탈 것이 나생활용품은 문화적으로 차이가 있는 낱말들이 대체되었다.

\section{한국판 CSBS DP 행동표본검사}

한국판 CSBS DP 행동표본검사는 12-24개월 영아의 의사소통 행동을 평가하기 위한 목적으로 Wetherby와 Prizant (2002)에 의 해 개발된 검사를 Lee 등(2018)이 수정 - 보완하여 우리나라 영아를 대상으로 신뢰도와타당도를 검정한 것을 사용하였다. 검사는 CSBS $\mathrm{DP}$ 양육자설문검사와 동일하게 사회적, 발화적, 상징적 세 구성영 역과 정서 및 시선, 의사소통, 몸짓, 말소리, 낱말, 이해, 사물사용의 7 개의 세부요인으로 이루어져 있으며, 훈련된 검사자가 직접 4 가지 의 반구조화된 절차로 행동표본을 수집하여 체계화된 절차로 채 점하도록 되어 있다. 문항내적일관도를 통해 신뢰도가 보고되었으 며, 타당도는 SELSI (Kim et al., 2003)와의 공인타당도, 확인적 요인 분석을 통한 구인타당도, 연령 집단 간의 유의한 발달적 타당도가 보고되었다. 본 연구에는 CSBS DP 양육자설문검사의 공인타당도 평가를 위한 도구로 포함하였다.

\section{영유아 언어발달검사}

Kim 등(2003)에 의해 개발된 것으로, 부모보고 형식을 통해 생 후 4-35개월 영유아의 전반적인 언어 및 의사소통 능력을 평가하는 검사 도구이다. 수용 및 표현언어 영역으로 구성되어 있으며, 각 영 역은 의미, 음운, 구문 및 화용 영역의 항목이 포함되어 있다. 국내 영유아 1,005 명을 대상으로 표준화 되었으며, 문항내적일치도와 재 검사 신뢰도를 통해 신뢰도가 난이도와 변별도를 통해 타당도가 보고되어 있다. CSBS DP 행동표본검사와 마찬가지로 CSBS DP 양 육자설문검사의 공인타당도 평가를 위한 도구로 포함하였다. 
Yoonkyoung Lee, et al. - The Reliability and Validity of the K-CSBS DP Caregiver Questionnaire

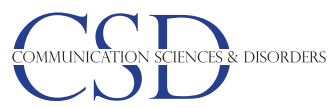

\section{영아선별·교육진단검사(DEP)}

Chang 등(2008)에 의해 장애위험 가능성이 있는 영아를 조기에 선별하고, 발달 수준을 파악해서 개별화교육프로그램(IEP)을 실 행하기 위한 목적으로 개발된 검사로 본 연구에서는 연구참가 영 아의 발달이 전형적으로 이루어지는지 확인하기 위하여 포함하였 다. 0-36개월 사이에 있는 영유아를 대상으로 6개 발달영역(대근육 운동기술, 소근육 운동기술, 의사소통, 사회정서, 인지, 기본생활) 을 평가하도록 구성되어 있다. 부모, 양육자, 교사가 직접 관찰해서 수행 여부를 검사할 수 있으며, 대상 영아를 관찰한 경험이 없는 제 3 의 평가자가 부모, 양육자, 교사를 대상으로 면접 질문을 통해 검 사할 수 있다. 총 861 명을 대상으로 표준화되어 있으며, 문항내적일 치도, 재검사신뢰도, K-ASQ와의 공인타당도가 보고되어 있다.

\section{자료수집}

연구참가자는 영아 양육자들이 활동하는 인터넷 카페(예: 맘카 페), 병원, 어린이집, 언어임상센터 등에 연구참가자 모집 안내문을 공지 또는 배포하여 모집하였다. 모집 안내문을 보고 참여 의사를 밝힌 경우에는 연구자가 직접 방문하거나 우편을 통해 자료를 보내 어 작성하게 하였다. 검사자가 가정으로 직접 방문한 경우에는 연구 의 목적을 설명한 후 동의서를 작성하게 하였으며, 기본정보조사지, CSBS DP 양육자설문검사, SELSI, DEP을 양육자가 직접 읽고 완료 하게 하였다. 각 검사지 작성 중에 질문이 있는 경우에는 검사자가 설명하여 완성할 수 있도록 하였다. 직접 방문이 어려운 경우에는 우편을 통해 동의서를 포함한 모든 자료와 검사 실시 절차를 요약 한 참고자료를 발송하여 자료를 수집하였다. 이 경우 양육자와 전 화 통화를 통해 연구 목적을 설명하여 동의서를 작성하게 하였으 며, 전화로 검사 실시 방법에 대해 안내하였다. 검사지 작성 시 질문 이 있으면 전화 통화를 통해 안내하였다. 우편을 통해 검사지를 발 송하는 경우 반송 봉투를 함께 보내고 발송 후 1 주일 내에 회수될 수 있도록 안내하였으며, 회수되지 않을 경우 개별적으로 연락하여 회수하였다. 검사지가 회수된 이후에는 먼저 기록에 문제가 없는지 점검하고, 혹시 기록이 정확하지 않은 경우에는 전화로 확인하여 보완하였으며, 보완되지 않은 경우는 자료에서 제외하였다.

12 개월 이상에 해당하는 연구참가자 중 양육자가 동의한 경우 에는 CSBS DP 행동표본검사를 실시하였다. 본 연구에는 총 157 명 의 영아가 행동표본검사에 참여하였다. 행동표본검사는 Lee 등 (2018)의 절차를 따라 실시하였다.

\section{자료분석 및 측정}

CSBS DP 양육자설문검사는 미국판 원검사의 채점 체계에 따라
Table 3. Construction of Caregiver Questionnaire of CSBS DP

\begin{tabular}{lcc}
\hline & Number of items & Range of score \\
\hline Cluster & & \\
Emotion \& eye-gaze & 8 & $0-16$ \\
Communication & 10 & $0-20$ \\
Gestures & 2 & $0-12$ \\
Sounds & 4 & $0-16$ \\
Words & 4 & $0-24$ \\
Understanding & 4 & $0-24$ \\
Object use & 8 & $0-27$ \\
Composite & & \\
Social (Emotion \& eye-gaze+ & 20 & $0-48$ \\
$\quad$ communication+gestures) & & \\
Communication (sounds+words) & 8 & $0-40$ \\
Symbolic (understanding+object use) & 12 & $0-51$ \\
Total & 40 & $0-139$ \\
\hline
\end{tabular}

CSBS DP = Communication and Symbolic Behavior Scale-Developmental Profile (Wetherby \& Prizant, 2002).

채점하였다. 문항별 반응 체계는 대부분 안함(0), 가끔(1), 자주(2) 의 3점 척도로 구성되었고, 일부 문항에서는 영아에게 관찰되는 행 동에 모두 체크를 하도록 되어 있다. 문항별 점수는 7개의 세부요인 과 3 개의 구성영역, 그리고 총점으로 합산될 수 있으며 문항 41 개의 최대 점수의 합은 139 점이었다(Table 3 ).

한국판 CSBS DP 행동표본검사와 SELSI 결과 역시 검사 실시 요 강에 제시된 절차에 따라 연구자들이 직접 채점하였다. 한국판 CSBS DP 행동표본검사는 총점과, 세 구성영역 점수, 그리고 7개의 세부요인 점수를 측정하였으며, SELSI는 표현언어 연령, 수용언어 연령, 통합언어 연령을 측정하였다.

\section{통계분석}

신뢰도는 Cronbach $\alpha$ 를 통해 문항내적일관도를 측정하였으며, 타당도는 확인적 요인분석을 통한 구인타당도와 한국판 CSBS DP 행동표본검사 및 SELSI와의 상관분석을 통한 공인타당도, 연령 집 단 간의 일원분산분석과 Tukey 사후 검정을 통한 발달적 타당도를 검정하였다. 한국판 CSBS DP 행동표본검사 및 SELSI와의 상관분 석은 각각의 검사를 동시에 수행한 157 명과 315 명의 자료만을 분석 하였다. 자료 통계분석에 사용한 프로그램은 SPSS ver. 25였다.

\section{연구결과}

\section{한국판 CSBS DP 양육자설문검사의 신뢰도 분석 결과}

총점, 세 구성영역별 점수, 7 개의 세부요인 별 점수에 대한 Cronbach $\alpha$ 로 문항내적일관도를 측정한 결과, 총점에 대한 문항내적일 
관도는 .94, 사회적 영역 .85, 발화적 영역 .87, 상징적 영역 .91로 높 은 문항내적일치도가 측정되었다. 7 개의 세부요인에서는 정서 및 시선이 .36으로 낮게 측정되었으나 이를 제외한 나머지는 모두 .72.89 사이의 높은 문항내적일치도를 보였다(Table 4$).$

\section{한국판 CSBS DP 양육자설문검사의 타당도 분석 결과} 공인타당도

공인타당도는 한국판 CSBS DP 행동표본검사 및 SELSI와의 Pearson 상관계수로 측정하였다. 자료분석 및 측정 부분에서 서술한 바와 같이 한국판 CSBS DP 행동표본검사 및 SELSI와의 상관분석은 각각 의 검사를 동시에 수행한 157 명과 315 명의 영아자료만을 포함하였다.

먼저, 한국판 CSBS DP 행동표본검사와의 상관분석 결과에서는 두 검사의 총점이 $r=.772(p<.01)$ 로 서로 높은 정적 상관을 보였으 며, 세 구성영역에서는 발화적 영역 $r=.784(p<.01)$, 상징적 영역 $r=.710(p<.01)$ 로 점수들 간에 높은 정적 상관을 보였다. 사회적 영 역 간에도 $r=.286$ ( $p<.01)$ 로 유의한 정적 상관을 보였다(Table 5).

Table 4. Cronbach a of the CSBS DP Caregiver Questionnaire

\begin{tabular}{lc}
\hline Variables & Cronbach's $\alpha$ \\
\hline Social & .85 \\
Emotion \& eye-gaze & .36 \\
Communication & .88 \\
Gestures & .82 \\
Speech & .87 \\
Sounds & .72 \\
Words & .83 \\
Symbolic & .91 \\
Comprehension & .75 \\
Object use & .89 \\
Total & .94 \\
\hline
\end{tabular}

CSBS DP=Communication and Symbolic Behavior Scale-Developmental Profile (Wetherby \& Prizant, 2002).

Table 5. Concurrent correlation between Caregiver Questionnaire of CSBS DP and Behavior Sample of CSBS DP

\begin{tabular}{|c|c|c|c|c|}
\hline & \multicolumn{4}{|c|}{ Caregiver Questionnaire } \\
\hline & Total & Social & Speech & Symbolic \\
\hline \multicolumn{5}{|c|}{ Behavior sample } \\
\hline Total & $.772^{* *}$ & $.270^{* *}$ & $.782^{* *}$ & $.713^{* *}$ \\
\hline Social & $.519^{* *}$ & $.286^{* *}$ & $.448^{* *}$ & $.508^{* *}$ \\
\hline Speech & $.665^{* *}$ & .143 & $.784^{* *}$ & $.547^{* *}$ \\
\hline Symbolic & $.704^{* *}$ & $.277^{* *}$ & $.638^{* *}$ & $.710^{* *}$ \\
\hline
\end{tabular}

CSBS DP=Communication and Symbolic Behavior Scale-Developmental Profile (Wetherby \& Prizant, 2002).

${ }^{* *} p<.01$.
SELSI와의 상관분석 결과에서는 CSBS DP 양육자설문검사 총 점이 SELSI 수용언어, 표현언어, 통합언어 연령과 $r=.870-.900$ 으로 높은 정적 상관을 보였으며, 세 구성영역에서는사회적 영역이 $r=.582-$ .624 , 발화적 영역 $r=.849-.905$, 상징적 영역 $r=.846-.895$ 로 SELSI 수용언어, 표현언어, 통합언어 연령과 유의한 정적 상관을 보였다. 또한 7개의 세부요인들도 정서 및 시선 요인을 제외한 나머지 요인 들이 SELSI 수용언어, 표현언어, 통합언어 연령과 $r=.561-.895$ 사이 의 유의한 정적상관을 보였다(Table 6).

\section{구인타당도}

$\mathrm{CSBS}$ DP가 이미 검사의 구성을 갖추고 출판된 검사이므로 확인 적 요인분석을 통해 구인타당도를 분석하였다. 분석결과, 3요인 구 조가 유의한 것으로 확인되었으며 $\left(\chi^{2}=3171.959, p<.001\right)$, 모델의 적합도를 알아보는 $\chi^{2} / \mathrm{df}$ 값은 $4.24, \mathrm{RMSEA}$ 는 $.07, \mathrm{CFI}$ 는 $.86, \mathrm{TLI}$ 는 .85로 나타나 검사에서 평가하는 3요인 구조가 수집된 자료에 잘 부합된 모형임이 확인되었다(Table 7).

\section{발달적 타당도}

CSBS DP 양육자설문검사가 연령에 따른 발달적 변화를 잘 반영

Table 6. Concurrent correlation between Caregiver Questionnaire of CSBS DP and SESLI

\begin{tabular}{llll}
\hline CSBS-DP & \multicolumn{3}{c}{ SELSI (N=315) } \\
\cline { 2 - 4 } Caregiver Questionnaire & ELA & RLA & CLA \\
\hline Social & $.582^{* *}$ & $.624^{* *}$ & $.621^{* *}$ \\
Emotion \& eye-gaze & $.120^{*}$ & .109 & $.116^{*}$ \\
Communication & $.561^{* *}$ & $.608^{* *}$ & $.603^{* *}$ \\
Gestures & $.640^{* *}$ & $.691^{* *}$ & $.686^{* *}$ \\
Speech & $.905^{* *}$ & $.849^{* *}$ & $.898^{* *}$ \\
Sounds & $.802^{* *}$ & $.783^{* *}$ & $.814^{* *}$ \\
Words & $.895^{* *}$ & $.824^{* *}$ & $.879^{* *}$ \\
Symbolic & $.846^{* *}$ & $.893^{* *}$ & $.895^{* *}$ \\
Comprehension & $.823^{* *}$ & $.858^{* *}$ & $.864^{* *}$ \\
Object use & $.804^{* *}$ & $.861^{* *}$ & $.858^{* *}$ \\
Total & $.870^{* *}$ & $.883^{* *}$ & $.900^{* *}$ \\
\hline
\end{tabular}

CSBS DP=Communication and Symbolic Behavior Scale-Developmental Profile (Wetherby \& Prizant, 2002); SESLI = Sequenced Language Scale for Infants (Kim, Kim, Yoon, \& Kim, 2003); ELA= expressive language age; RLA= receptive language age; $C L A=$ combined language.

${ }^{*} p<.05,{ }^{* *} p<.01$.

Table 7. Result of confirmation factor analysis

\begin{tabular}{ccccccc}
\hline & $d f$ & $\chi^{2}$ & $p$-value & CFI & TLI & RMSEA \\
\hline Factor model & 748 & 3171.959 & $<.001$ & .86 & .85 & .068 \\
\hline
\end{tabular}


Table 8. Result of ANOVA according to age group

\begin{tabular}{|c|c|c|c|c|c|c|c|c|c|c|c|}
\hline Variables & $F$ & Group & $6-7$ & $8-9$ & $10-11$ & 12 & $13-14$ & $15-16$ & $17-18$ & $19-20$ & $21-22$ \\
\hline \multirow[t]{9}{*}{ Social } & $100.450^{* * *}$ & $8-9$ & $* *$ & & & & & & & & \\
\hline & & $10-11$ & $* * *$ & $* *$ & & & & & & & \\
\hline & & 12 & $* * *$ & $* * *$ & $* *$ & & & & & & \\
\hline & & $13-14$ & $* * *$ & $* * *$ & $* * *$ & & & & & & \\
\hline & & $15-16$ & $* * *$ & $* * *$ & $* * *$ & $* * *$ & & & & & \\
\hline & & 17-18 & $* * *$ & $* * *$ & $* * *$ & $* * *$ & & & & & \\
\hline & & $19-20$ & $* * *$ & $* * *$ & $* * *$ & $* * *$ & & & & & \\
\hline & & $21-22$ & $* * *$ & $* * *$ & $* * *$ & $* * *$ & & & & & \\
\hline & & 23-24 & $* * *$ & $* * *$ & $* * *$ & $* * *$ & * & & & & \\
\hline \multirow[t]{9}{*}{ Speech } & $86.935^{* * *}$ & $8-9$ & & & & & & & & & \\
\hline & & $10-11$ & & & & & & & & & \\
\hline & & 12 & $* *$ & & & & & & & & \\
\hline & & $13-14$ & $* * *$ & * & & & & & & & \\
\hline & & $15-16$ & $* * *$ & $* * *$ & $* * *$ & $* *$ & & & & & \\
\hline & & 17-18 & $* * *$ & $* * *$ & $* * *$ & $* * *$ & $* *$ & & & & \\
\hline & & $19-20$ & $* * *$ & $* * *$ & $* * *$ & $* * *$ & $* * *$ & $* * *$ & & & \\
\hline & & $21-22$ & $* * *$ & $* * *$ & $* * *$ & $* * *$ & $* * *$ & $* * *$ & $* * *$ & * & \\
\hline & & 23-24 & $* * *$ & $* * *$ & $* * *$ & $* * *$ & $* * *$ & $* * *$ & $* * *$ & $* * *$ & $* * *$ \\
\hline \multirow[t]{9}{*}{ Symbolic } & $268.290^{* * *}$ & $8-9$ & & & & & & & & & \\
\hline & & $10-11$ & $* *$ & $* *$ & & & & & & & \\
\hline & & 12 & $* * *$ & $* * *$ & $* *$ & & & & & & \\
\hline & & $13-14$ & $* * *$ & $* * *$ & $* * *$ & $* * *$ & & & & & \\
\hline & & $15-16$ & $* * *$ & $* * *$ & $* * *$ & $* * *$ & $* * *$ & & & & \\
\hline & & $17-18$ & $* * *$ & $* * *$ & $* * *$ & $* * *$ & $* * *$ & * & & & \\
\hline & & $19-20$ & $* * *$ & $* * *$ & $* * *$ & $* * *$ & $* * *$ & $* * *$ & $* *$ & & \\
\hline & & $21-22$ & $* * *$ & $* * *$ & $* * *$ & $* * *$ & $* * *$ & $* * *$ & $* * *$ & & \\
\hline & & $23-24$ & $* * *$ & $* * *$ & $* * *$ & $* * *$ & $* * *$ & $* * *$ & $* * *$ & $* *$ & \\
\hline \multirow[t]{9}{*}{ Total } & $207.702^{* * * *}$ & $8-9$ & & & & & & & & & \\
\hline & & $10-11$ & $* * *$ & * & & & & & & & \\
\hline & & 12 & $* * *$ & $* * *$ & * & & & & & & \\
\hline & & $13-14$ & $* * *$ & $* * *$ & $* * *$ & * & & & & & \\
\hline & & $15-16$ & $* * *$ & $* * *$ & $* * *$ & $* * *$ & $* *$ & & & & \\
\hline & & $17-18$ & $* * *$ & $* * *$ & $* * *$ & $* * *$ & $* * *$ & & & & \\
\hline & & $19-20$ & $* * *$ & $* * *$ & $* * *$ & $* * *$ & $* * *$ & $* * *$ & * & & \\
\hline & & $21-22$ & $* * *$ & $* * *$ & $* * *$ & $* * *$ & $* * *$ & $* * *$ & $* * *$ & & \\
\hline & & 23-24 & $* * *$ & $* * *$ & $* * *$ & $* * *$ & $* * *$ & $* * *$ & $* * *$ & $* *$ & $* *$ \\
\hline
\end{tabular}

${ }^{*} p<.05 .{ }^{* *} p<.01,{ }^{* * *} p<.001$

하는가를 확인하기 위해 월령 집단을 독립변인으로 총점과 세 구 성영역 점수에 대해 일원분산분석과 Tukey 사후분석을 실시하였 다. 분석결과, 총점을 비롯하여 3 개의 구성영역 모두 월령에 따른 유의한 차이가 있는 것으로 나타났다. 총점은 6-7개월과 8-9개월, $15-16$ 개월과 17-18개월, 그리고 19-20개월과 21-22개월 집단 사이 를 제외한 모든 월령 집단 간에 유의한 차이가 있었다(Table 8). 세 구성영역 점수 중에서는 발화적 영역과 상징적 영역은 거의 모든 월령 집단 간에 유의한 차이를 보인 반면, 사회적 영역은 13-14개월
월령 집단까지는 집단 간에 유의한 차이를 보였으나, 15-16개월에 서 23-24개월 사이에서는 유의한 차이가 없었다(Table 8).

\section{논의 및 결론}

본 연구는 우리나라 영아를 대상으로 CSBS DP 양육자설문검사 의 신뢰도와타당도를 확인하기 위한 목적으로 실시하였다. 신뢰도 는 Chronbach $\alpha$ 문항내적일관도를 통해 검정하였으며, 타당도는 
CSBS DP 행동표본검사 및 SELSI와의 상관분석을 통한 공인타당 도와, 확인적 요인분석을 통한 구인타당도, 그리고 연령 집단 간의 차이검정을 통해 발달적 타당도를 검정하였다.

먼저 신뢰도 분석 결과, 총점의 Chronbach $\alpha$ 값이 .94로 매우 높 은 문항내적일관도가 측정되었다. 세 구성영역에서는 사회적 영역 이 .85, 발화적 영역이 .87 , 상징적 영역이 .91로 모두 높은 문항내적 일관도를 보였다. 이는 미국 영아를 대상으로 한 CSBS DP의 원검 사에서 보고된 총점의 Chronbach $\alpha$ 값 .93, 세 구성영역인 사회적 영역 .88 , 발화적 영역 .88 , 상징적 영역 .87 과 유사한 수치이다(Wetherby \& Prizant, 2002). 문항내적일관도는 일반적으로 $\alpha$ 값이 .60 이 상인 경우 신뢰도가 있다고 보며, .80 이 넘으면 높은 신뢰도를 갖는 다고 해석한다(Sung, 2015). 따라서 총점과 세 구성영역 점수를 중 심으로 보았을 때, CSBS DP 양육자설문검사가 우리나라 영아에게 도 높은 신뢰도를 갖는 검사라 할수 있다.

7 개의 세부요인의 Chronbach $\alpha$ 값도 .36으로 측정된 정서 및 시 선 요인을 제외한 나머지 요인들이 모두 .72-.89 사이의 $\alpha$ 값을 보여 대'체로 높거나 안정된 수준의 신뢰도를 보였다. 미국 영아를 대상 으로 한 원검사에서는 정서 및 시선 요인을 포함한 7 개의 세부요인 모두 .87-90의 수치를 보고하였다. 우리나라 영아 자료가 약간 낮 은 수치이기는 하나 대체로 정서 및 시선 요인 결과를 제외하고는 세부요인 점수도 신뢰도가 높다고 할 수 있다. 반면 정서 및 시선 요 인에서는 Chronbach $\alpha$ 값이 낮게 측정되었는데, 이는 CSBS DP 양 육자설문검사만이 아니라 국내 영아들을 대상으로 이루어진 CSBS DP 행동표본검사의 신뢰도 및 타당도 연구(Lee et al., 2018)에서도 보고된 바가 있다. CSBS DP 행동표본검사 연구에서는 이러한 결 과에 대해 낯선 행동 표본 수집 상황이 영아들의 정서 표현이나 시 선 사용에 영향을 미쳤을 수도 있으며, 우리나라 문화가 미국에 비 해 상대적으로 눈맞춤이나 정서 표현이 적기 때문에 나타난 결과 일 수 있다는 두 가지 측면에서 논의하였다. 본 연구는 검사자가 아 동에게 직접 얻은 자료가 아니라 양육자보고를 통해 얻어진 결과 이므로 상황적 요소가 개입될 여지가 거의 없기 때문에 전자보다 는 후자의 설명이 더 타당하게 받아들여질 수 있다. 남아프리카 영 아들에게 CSBS DP 행동표본검사 결과를 미국판 규준 자료와 비 교한 연구(Chambers, Stonach, \& Wetherby, 2016)에서도 정서 및 시선 요인에서만 .22 로 매우 낮은 수치를 보고한 바 있다. CSBS DP 양육자설문검사가 아니고 행동표본검사에서 얻어진 결과이기는 하나 이 역시 다른 요인들에 비해 시선 및 응시 요인이 어느 정도는 문화적 영향을 받을 수 있음을 시사한다.

타당도는 CSBS DP 행동표본검사 및 SELSI와의 상관분석을 통 한 공인타당도와 확인적 요인분석을 통한 구인타당도, 그리고 연령
집단 간의 차이검정을 통한 발달적 타당도 세 가지로 검정하였다. 먼저 CSBS DP 행동표본검사 결과와의 상관분석은 미국판 원검사 와 동일하게 총점과 세 구성영역에 대해서만 실시하였다. 결과를 보 면, 총점에서는 .772, 발화적 영역 .784, 상징적 영역 .710으로 모두 높은 상관을 보였다. 미국판 원검사에서는 연령 집단별로 별도로 상관분석을 실시했는데, $12-17$ 개월은 총점 .66, 발화적 영역은 .62, 상징적 영역은 .63, 18-24개월은 총점 .71, 발화적 영역과 상징적 영 역은 $.76, .58$ 의 상관계수를 보고하여 대체로 원검사보다 높은 정적 관계를 나타냈다. 사회적 영역은 미국 원검사에서는 두 연령 집단 모두 .44로 나타난 반면 본 연구에서는 .286으로 통계적으로는 유 의하였으나 상대적으로 낮은 상관계수를 보였다. 이는 즉, CSBS DP 행동표본검사(Lee et al., 2018)와 양육자설문검사 모두 낮은 신 뢰도를 보인 정서 및 응시 점수가 포함된 것이 영향을 미친 것으로 판단된다.

SELSI의 표현언어 연령, 수용언어 연령, 통합언어 연령과 상관분 석을 실시한 결과는 총점이 .883-900으로 매우 높은 상관을 보였으 며, 사회적 영역 .582-.624, 발화적 영역.849-.905, 상징적 영역.846.895의 높은 정적 상관을 보였다. 또한 7 개의 세부요인 점수들도 정 서 및 시선 요인을 제외한 나머지 요인들이 .561-.895로 유의한 정적 상관을 보였다. 상관계수를 보면 같은 구인을 평가한 CSBS DP 행 동표본검사 결과보다도 높은 측정치를 보였으며, 특히 언어표현과 관계가 깊은 발화적 영역과 언어이해 및 상징발달을 보는 상징적 영 역, 그리고 그에 해당하는 세부요인들 모두 매우 높은 상관을 나타 냈는데 이는 초기 의사소통 발달이 언어 발달과 밀접하게 관련된 다는 선행연구(Calandrell \& Wilcox, 2000; Chiat \& Roy, 2008; Choi \& Lee, 2018; Lee \& Lee, 2016; Watt et al., 2006)를 지지해주는 결과 라 할 수 있다. 또한 CSBS DP 양육자설문검사와 SELSI는 공통적 으로 양육자 보고 방식을 취하고 있는데, 두 검사 간의 높은 상관은 양육자들이 일관되게 아동의 언어와 의사소통을 평가한다는 것을 반영한다.

확인적 요인분석을 통한 구인타당도 검정 결과도 한국판 CSBS $\mathrm{DP}$ 행동표본검사(Lee et al., 2018)에서 보고된 것과 마찬가지로 CSBS DP 양육자설문검사가 원검사(Wetherby \& Prizant, 2002)의 3 요인 구조를 갖추고 있으며, 모형의 적합도도 높은 검사임을 입증 하였다. 구인타당도는 검사가 측정하고자 하는 개념을 평가할 수 있는 요인들로 잘 구성되어 있는가를 보여 주는 것으로 타당도 검 정에서 가장 강조된다(Haynes \& Pinzola, 2008). 검사를 구성하는 하위검사 간의 상관분석이나 요인분석 등의 방법 등이 활용되는 데, 본 연구에서는 CSBS DP 양육자설문검사가 이미 원검사에서 구성요인이 제시되어 있는 검사이므로 가정된 요인구조를 자료에 
Yoonkyoung Lee, et al. - The Reliability and Validity of the K-CSBS DP Caregiver Questionnaire

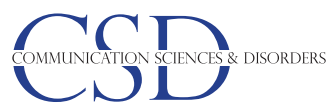

적용시켜서 그 구조의 타당성을 확인하는 확인적 요인분석 방법을 통해 검정하였으며(Sung, 2015), 이 역시 CSBS DP 양육자설문검사 가 우리나라 영아 검사로도 타당한 검사임을 확인해 주었다.

마지막으로 연령 집단 간의 차이 검정을 통한 발달적 타당도에서 총점을 비롯하여 3 개의 구성영역 모두 월령에 따른 유의한 차이가 있는 것으로 나타났다. 총점은 6-7개월과 8-9개월 사이, 15-16개월 과 17-18개월 사이, 그리고 19-20개월과 21-22 세 집단 사이를 제외 한 모든 월령 집단 사이에서 유의한 차이가 있었다. 세 구성영역 점 수 중에서는 발화적 영역과 상징적 영역은 거의 모든 월령 집단 간 에 유의한 차이를 보인 반면, 사회적 영역은 13-14개월 월령 집단까 지는 집단 간에 유의한 차이를 보였으나, 15-16개월에서 23-24개월 사이에서는 유의한 차이가 없었다. 이러한 결과는 대체로 월령이 증 가함에 따라 CSBS DP 점수도 유의하게 증가하여 CSBS DP 양육자 설문검사가 초기 의사소통 발달 정도를 평가하는 도구로써 타당하 게 활용될 수 있음을 보여 준다. 특히 사회적 영역 점수는 18 개월 미 만의 어린 영아들에게, 그리고 총점을 비롯한 발화적, 상징적 영역 점수는 24 개월까지 발달적 양상을 반영해 줄수 있음을 시사한다.

본 연구를 통하여 CSBS DP 양육자설문검사가 우리나라 영아들 에게도 신뢰롭고 타당한 도구임을 확인하였다. CSBS DP 행동표본 검사는 우리나라(Lee et al., 2018)는 물론 중국과 대만(Lin \& Chiu, 2014; Lin, Chang, Cheng, Chao, \& Chiu, 2015), 남아프리카공화국 (Chambers et al., 2016), 오스트레일리아(Eadie et al., 2010) 등 여러 나라 아동들을 대상으로 신뢰도와 타당도가 보고된 바가 있으나, 양육자설문검사의 신뢰도와 타당도는 상대적으로 많이 검정되지 않았다. 나이가 어린 영유아 평가는 반드시 가족 중심, 또는 가족 참여 평가가 되어야 하며, 검사자의 평가 결과와 통합하고 종합하 여야 한다(Crais, 2011; Lee, 2019; Lynch \& Hanson, 2004). 본 연구 를 통해 신뢰도와 타당도가 확인된 CSBS DP 양육자설문검사가 초기 의사소통 발달 수준에 있는 아동들의 의사소통 평가에는 물 론 아동 평가에의 가족 참여에도 기여할 수 있을 것이다.

\section{REFERENCES}

Calandrella, A. M., \& Wilcox, M. J. (2000). Predicting language outcomes for young prelinguistic children with developmental delay. Journal of Speech, Language, and Hearing Research, 43(5), 1061-1071.

Chiat, S., \& Roy, P. (2008). Early phonological and sociocognitive skills as predictors of later language and social communication outcomes. Journal of Child Psychology and Psychiatry, 49(6), 635-645.

Chambers, N., Stronach, S. T., \& Wetherby, A. M. (2016). Performance of
South African children on the Communication and Symbolic Behavior Scales-Developmental Profile (CSBS DP). International Journal of Language \& Communication Disorders, 51(3), 265-275.

Choi, J. J., \& Lee, Y. (2018). Communicative gestures in prelinguistic periods as predictors of later language development in Korean toddlers. Communication Sciences \& Disorders, 23(1), 11-19.

Crais, E. R. (2011). Testing and beyond: strategies and tools for evaluating and assessing infants and toddlers. Language, Speech, and Hearing Services in Schools, 42(3), 341-364.

Dale, P. S., Price, T. S., Bishop, D. V., \& Plomin, R. (2003). Outcomes of early language delay. I. Predicting persistent and transient language difficulties at 3 and 4 years. Journal of Speech, Language, and Hearing Research, 46(3), 544-560.

Eadie, P. A., Ukoumunne, O., Skeat, J., Prior, M. R., Bavin, E., Bretherton, L., \& Reilly, S. (2010). Assessing early communication behaviours: structure and validity of the Communication and Symbolic Behaviour Scales-Developmental Profile (CSBS DP) in 12-month-old infants. International Journal of Language \& Communication Disorders, 45(5), 572-585.

Henrichs, J., Rescorla, L., Schenk, J. J., Schmidt, H. G., Jaddoe, V. W., Hofman, A., ... \& Tiemeier, H. (2011). Examining continuity of early expressive vocabulary development: the generation R study. Journal of Speech, Language, and Hearing Research, 54(3), 854-869.

Hong, G. H., \& Kim, Y. T. (2005). A longitudinal study of predictors for expressive vocabulary development of late-talkers. Korean Journal of Communication \& Disorders, 10(1), 1-24.

Haynes, W. O., \& Pinzola, R. H. (2008). Assessment of school-age and adolescent language disorders. In Diagnosis and evaluation in speech pathology (7th ed.). Boston: Pearson Education

Iverson, J. M., \& Goldin-Meadow, S. (2005). Gesture paves the way for language development. Psychological Science, 16(5), 367-371.

Jang, H. S., Seo, S. J., \& Ha, J. Y. (2011). Developmental assessment for the Early intervention Program planning (DEP). Seoul: Hakjisa.

Kim, M. J., Pae, S. Y., \& Park, C. I. (2007). Assessment of Phonology \& Articulation for Children (APAC). Incheon: Human Brain Research \& Counseling.

Kim, Y. T., Kim, K. H., Yoon, H. R., \& Kim, H. S. (2003). Sequenced Language Scale for Infants (SELSI). Seoul: Special Education Publishing.

Lee, H. R., Chang, Y. K., Choi, Y. L., \& Lee, S. B. (2009). Lexical acquisition of Korean infants: characteristics of early expressive vocabulary. Journal of Speech-Language \& Hearing Disorders, 18(3), 65-80. 
Lee, Y. (2011). The relationships among language, communicative abilities and motor, cognitive, and socio-emotional development in toddlers with language delays. Korean Journal of Communication \& Disorders, 16(1), 1-12.

Lee, Y. (2019). Communication disorders in infants and toddlers: development, assessment, and intervention. Seoul: Hakjisa.

Lee, Y., \& Lee, H. (2016). Development of intentional communicative behavior in Korean toddlers 12 to 30 months. Communication Sciences \& Disorders, 21(4), 553-566.

Lee, Y., \& Lee, H. (2019). Early social communication profile of Korean late talkers via the CSBS DP. Communication Sciences \& Disorders, 24(2), 263 273.

Lee, Y., Lee, H., \& Choi, J. (2018). A study of validity and reliability of the CSBS DP Behavior Sample in Korean toddlers. Communication Sciences \& Disorders, 23(2), 539-548.

Lin, C. S., Chang, S. H., Cheng, S. F., Chao, P. C., \& Chiu, C. H. (2015). The preliminary analysis of the reliability and validity of the Chinese edition of the CSBS DP. Research in Developmental Disabilities, 38, 309-318.

Lin, C. S., \& Chiu, C. H. (2014). Adaptation of the Chinese edition of the CSBS DP: a cross-cultural comparison of prelinguistic development between Taiwanese and American toddlers. Research in Developmental Disabilities, 35(5), 1042-1050.

Lynch, E., \& Hanson, M. (2004). Family diversity, assessment, and cultural competence. In M. McLean, D. Bailey, \& M. Wolery (Eds.), Assessing infants and preschoolers with special needs (4th ed., pp. 69-95). Columbus, OH: Merrill.

Pae, S., \& Kwak, K. (2011). Korean McArthur Bates Communication Development Inventory. Seoul: Mind Press.

Paul, R., Looney, S. S., \& Dahm, P. S. (1991). Communication and socialization skills at ages 2 and 3 in "late-talking" young children. Journal of Speech,
Language, and Hearing Research, 34(4), 858-865.

Rescorla, L. A. (2013). Late-talking toddlers: a 15-year follow-up. In L. A. Rescorla \& P. S. Dale (Eds.), Late talkers: language development, interventions and outcomes (pp. 219-239). Baltimore, MD: Brookes.

Rescorla, L., Roberts, J., \& Dahlsgaard, K. (1997). Late talkers at 2: outcome at age 3. Journal of Speech, Language, and Hearing Research, 40(3), 556-566.

Rossetti, L. M. (2001). Communication intervention: birth to three. San Diego, CA: Cengage Learning.

Sung, T. J. (2015). Research methods of education. Seoul: Hakjisa.

Thal, D. J., \& Tobias, S. (1992). Communicative gestures in children with delayed onset of oral expressive vocabulary. Journal of Speech, Language, and Hearing Research, 35(6), 1281-1289.

Thal, D., Tobias, S., \& Morrison, D. (1991). Language and gesture in late talkers: a 1-year follow-up. Journal of Speech, Language, and Hearing Research, 34(3), 604-612.

Tomblin, J. B., Records, N. L., Buckwalter, P., Zhang, X., Smith, E., \& O’Brien, M. (1997). Prevalence of specific language impairment in kindergarten children. Journal of Speech, Language, and Hearing Research, 40(6), 12451260.

Watt, N., Wetherby, A., \& Shumway, S. (2006). Prelinguistic predictors of language outcome at 3 years of age. Journal of Speech, Language, and Hearing Research, 49(6), 1224-1237.

Westerlund, M., Berglund, E., \& Eriksson, M. (2006). Can severely language delayed 3-year-olds be identified at 18 months? Evaluation of a screening version of the MacArthur-Bates Communicative Development Inventories. Journal of Speech, Language, and Hearing Research, 49(2), 237-247.

Wetherby, A. M., \& Prizant, B. M. (2002). CSBS DP manual: communication and symbolic behavior scales: developmental profile. Baltimore, MD: The Brookes Publishing. 


\section{국문초록}

\section{한국판 CSBS DP 양육자설문검사' 타당도 및 신뢰도 연구}

이윤경 ${ }^{1}$ 최지은 ${ }^{1}$ - 이효주 ${ }^{2}$

'한림대학교 언어청각학부, ${ }^{2}$ 한림언어발달연구원

배경 및 목적: 의사소통 및 상징 행동 척도(CSBS DP)는 영유아체크리스트(ITC), 행동표본검사, 양육자설문검사 세 가지 검사로 구성 되어 있다. 이 중 행동표본검사는 우리나라 아동들을 대상으로 신뢰도와 타당도가 보고되어 있으나 다른 두 검사는 신뢰도와 타당도 가 검정되어 있지 않다. 본 연구는 그 중 CSBS DP 양육자설문검사의 신뢰도와 타당도 검정을 목적으로 하였다. 방법: CSBS DP 양육자 설문검사를 한국어로 번역하고, 아동언어전문가 3인에게 타당도 검정을 받았다. 전형적 발달을 보이는 6-24개월 사이 영아 794명에게 CSBS DP 양육자설문검사를 실시하였으며, 이중 676명의 자료가 분석되었다. 문항내적일관도를 통해 신뢰도를 측정하였으며, K CSBD $\mathrm{DP}$ 행동표본검사와 SELSI와의 상관분석을 통한 공인타당도를, 확인적 요인분석을 통한 구인타당도를, 그리고 연령 집단 간의 차이 검 정을 통해 발달적 타당도를 검정하였다. 결과: 문항내적일관도를 통해 높은 신뢰도가 측정되었다. K CSBS DP 행동표본검사와 SELSI 점수와 유의한 상관을 보여 높은 공인타당도가 측정되었으며, 확인적 요인분석 결과도 높은 모형 적합도를 보여 구인타당도 역시 높은 것으로 나타났다. 연령에 따른 차이 검정 결과 발달적 타당도도 확인되었다. 논의 및 결론: CSBS DP 양육자설문검사도 행동표본검사 와 마찬가지로 타당도와 신뢰도가 높은 검사 도구로 확인되었다. 초기 의사소통 발달 수준의 전형적 발달 아동과 발달지체 아동의 의 사소통 평가에 활용될 수 있을 것이다.

핵심어: CSBS DP 양육자설문검사, 신뢰도, 타당도

이 연구는 2019년 한림대학교 교비연구비 지원을 받아 수행되었음(HRF-201909-014).

\section{참고문헌}

김민정, 배소영, 박창일 (2007). 아동용 발음검사(APAC). 서울: 휴브알엔씨.

김영태, 김경희, 윤혜련, 김화수 (2003). 영아 언어발달 선별검사(Sequenced Language Scale for Infant, SELSI). 서울: 도서출판특수교육. 배소영, 곽금주 (2011). 한국판 맥아더-베이츠 의사소통 발달평가 (K M-B CDI). 서울: 마인드프레스.

성태제 (2015). 교육 연구 방법의 이해. 서울: 학지사.

이윤경 (2011). 언어발달지체 영유아의 언어 및 의사소통 능력과 인지, 운동 및 사회성 발달과의 관계. 언어청각장애연구, 16(1), 1-12.

이윤경 (2019). 영유아 의사소통장애: 발달, 평가, 중재. 서울: 학지사.

이윤경, 이효주 (2016). 12-30개월 영아의 의도적 의사소통 행동 발달. Communication Sciences \& Disorders, 21(4), 553-566.

이윤경, 이효주 (2019). 한국판 CSBS DP를 통한 말늦은 영유아의 초기 사회적 의사소통 프로파일. Communication Sciences \& Disorders, 24(2), 263-273.

이윤경, 이효주, 최지은 (2018). 한국판 표준화를 위한 ‘CSBS DP 행동샘플평가'신뢰도 및 타당도 연구. Communication Sciences \& Disorders, 23(2), 539-548.

이희란, 장유경, 최유리, 이승복 (2009). 한국 아동의 어휘 습득: 초기 표현어휘의 특징. 언어치료연구, 18(3), 65-80. 장혜성, 서소정, 하지영 (2011). 영아선별 교육진단검사(developmental assessment for the early intervention program planning, DEP). 서울: 학지사. 최진주, 이윤경 (2018). 언어이전 시기의 의사소통 몸짓 사용이 24개월 언어발달에 미치는 영향에 관한 종단연구. Communication Sciences \& Disorders, 23(1), 11-19.

홍경훈, 김영태 (2005). 종단연구를 통한 ‘말늦은아동 (late-talker)’의 표현어휘발달 예측요인 분석. 언어청각장애연구, 10(1), 1-24. 


\section{ORCID}

이윤경(제1저자, 교신저자, 교수 https://orcid.org/0000-0002-9759-6247); 최지은(공동저자, 겸임교수 https://orcid.org/0000-0002-4141-4096); 이효주(공동저자, 겸임교수, 언어재활사 https://orcid.org/0000-0002-6908-1836) 